\title{
CHINA'S CULTURAL SOFT POWER: THE CENTRAL CONCEPT IN THE EARLY XI JINPING ERA (2012-2017)
}

ONDŘEJ KLIMEŠ

\begin{abstract}
China's leaders are aware that the country's emergence as a major power in the twenty-first century is preconditioned by acquiring soft power and a favourable national image. Culture and cultural projection are seen as essential resources in international strategy, which is conceived with regard to the domestic political objectives of the Communist Party of China (CPC). This paper examines the conceptual framework of China's cultural soft power during Xi Jinping's first term as general secretary (2012-2017). Drawing mostly on official statements by central party organs, the research identifies the rationale, values, and instruments of China's cultural soft power and national-image-building strategy, and also briefly assesses the limitations of this strategy. The article finds that CPC leadership does not clearly differentiate between domestic and foreign cultural work and instead considers domestic cultural security and international soft-power-building a single ideational and discursive enterprise designed to maintain the CPC's rule and gain international acknowledgement for it. The alleged uniqueness of China's culture and civilization, and, therefore, the China development model, is the main argument of this discourse. The central leadership's concept of culture as a political instrument for maintaining power thus shows little innovation from previous eras of the CPC's cultural governance. Its impact thus remains limited by the objective of legitimating authoritarian politics and compromises the CPC's efforts to present China as a major cultural power.
\end{abstract}

Keywords: China; Xi Jinping; propaganda; ideology; cultural soft power; national image 


\section{Introduction ${ }^{1}$}

In the essay The Captive Mind, Polish intellectual Czesław Miłosz recounts how communist regimes in Central and Eastern European began to rule the minds of their subjects shortly after World War II. He writes that in order to win the acknowledgment of their citizens, "people's democracies wage[d] a struggle over the human mind. People need to be ushered to understanding; once they understand, they will also accept" (Miłosz 1992: 174). Although today's People's Republic of China (PRC) is vastly different from the Eastern Bloc of sixty years ago, in both contexts the main political actor is a communist party seeking to elicit acceptance of its rule. Not only is domestic tolerance for the regime vital for its survival in the face of multiplying challenges to its rule, but also international approval is requisite for the intention of the Communist Party of China (CPC) to make China a global leader commanding soft power equivalent to its economic might. The CPC realizes that in order to hold and project power in the Information Age, it must have a good reputation at home and abroad. Although in the new millennium the party has dedicated substantial efforts at enhancing China's soft power and national image, and indeed "China's idea of China is [now] more noticeable around the world" (Rawnsley 2015: 460), international perceptions of China remain mixed. In liberal democratic countries, to whose opinions Chinese leaders attach high importance (as this paper shows below), the country is generally viewed in a neutral or unfavorable light, while it is seen favorably by developing and non-democratic states, which value China's "non-interference" in their internal politics (e.g., CSIS 2016, Pew Research Center 2016). Nonetheless, due to its lack of soft power, China remains what has been called "a partial cultural power" (Shambaugh 2013: 165).

China's public diplomacy and efforts at engendering positive public opinion about China have been analyzed in several recent studies, which agree that the state is no longer the exclusive actor in these processes. A volume edited by Jian Wang illustrates that China's primarily political project of national image management interplays with the powerful, fluid dynamics of business and the popular national consciousness (Wang, ed. 2011: 10-11). Ingrid d'Hooghe points out the growing number of actors involved in China's public diplomacy since the early 1990s. Among state actors, she notes a horizontal proliferation of governmental and party actors and a vertical proliferation of provincial and municipal governments. She also observes the growing diversity of what she calls "non-state" actors in China's public diplomacy that generate a diverse image of China which is perceived as more interesting and genuine than the image projected by the government (d'Hooghe 2015: 132-162). Falk Hartig sees China's Confucius Institutes as an example of the post-Cold War era's "new" public diplomacy. He contrasts the "old" public diplomacy, which was primarily designed to persuade, with the new public diplomacy, highlighting its emphasis on understanding the needs of foreign countries, finding common interests, and fostering collaboration, dialogue, communication via new

1 This study was supported by a Czech Science Foundation grant China's Cultural Diplomacy: Role of Non-State Actors and Regional Variations (GAČR GA5-21829S - 2015-2017). It is an outcome of the Oriental Institute's Power and Strategies of Social and Political Order research platform (http:// power.orient.cas.cz/). The author is thankful to two anonymous reviewers, Olga Lomová, Jitka Pánek Jurková, and Adrian Zenz for valuable comments and suggestions. 
technologies, and the emergence of new actors such as NGOs, advocacy groups, and nonstate actors (Hartig 2016: 7).

These studies, nevertheless, agree that in spite of the new trends China's cultural diplomacy is still primarily conceived and performed by state actors. Wang finds that "China's image building project remains largely a state-centric project", while Hartig sees China's public diplomacy as a "state-centric endeavor" of the old public diplomacy. D'Hooghe notes that China's authoritarian regime greatly impacts its public diplomacy and state actors far outnumber "non-state" actors. Moreover, 'non-state' actors are not fully autonomous, but, like all other social organizations in China, are regulated, supervised, and coopted by the party-state, which ensures that their activities do not conflict official policies. Kingsley Edney examines in detail the link between the CPC's domestic propaganda and the PRC's international communication, arguing that soft power strategies are designed with a simultaneous view to strengthening the political regime domestically (Edney 2014: 101-121).

The persisting prominence of party-state actors in China's public diplomacy and its link to domestic political objectives is the starting point for this research. In other words, since the party-state remains the central actor in China's public diplomacy, and indeed in all other political processes, this research shows that culture features strongly within the CPC's ideological outlook on how to solicit international understanding and acceptance, claim international discursive space and soft power, improve national image, and project the values of the People's Republic of China. This paper, therefore, explores how the CPC's central leadership conceptualizes China's cultural diplomacy, or, in other words, how it employs culture as a resource for public diplomacy, defined by one study as a country's communication and engagement with foreign publics in order to support national interest and to facilitate or project soft power (Hartig 2016: 1, 49; for a detailed conceptual overview of public diplomacy and soft power, see, e.g., d'Hooghe 2015: 16-46, Hartig 2016: 32-56).

This article approaches the CPC's central concept of China's cultural diplomacy as a basis for concerted ideational ${ }^{2}$ activity exerted both to reinforce domestic political order and to gain soft power abroad. The study focuses on the latest ideational design of “cultural soft power" (wenhua ruan shili 文化软实力) during Xi Jinping's 习近平 first term as general secretary beginning in 2012. The research purposefully draws on the monolithic official message uttered in the robotic newspeak of the CPC's central propaganda apparatus because it views these statements as a coherent and candid image of the party's cultural work and cultural diplomacy situated within the framework of both its overall ideational action and overall governance. In other words, this study explores the vision of the central leadership because this vision has a major impact on the practical doings of all political actors in the PRC. The pivotal source is Xi Jinping's keynote speech at the National Propaganda and Thought-Work Conference on 19 August 2013 (Xinhua 2013a), which can be considered the CPC's policy statement on propaganda and thought-

2 This paper generally prefers the term ideational to ideological in reference to the CPC's post-Mao “propaganda and thought-work” (宣传思想工作) because since 1978 the party has not aimed to inculcate a "hard" abstract ideological system, but rather a set of "softer", easily comprehensible ideational concepts, such as economic development, social stability, national rejuvenation, comprehensive deepening of reforms, and so forth. 
work for Xi Jinping's era of leadership (2012-?). The tenets of the speech were replicated and elaborated on in statements by the central propaganda apparatus, including leading official media and think tanks. These documents are a secondary source. The limitations of the central concept of China's cultural diplomacy are also briefly assessed at the end of this article.

\section{Culture as ideology and propaganda in the PRC}

In general, all CPC activities are organized into several major “systems” (xitong 系统), or policy spheres, that are coordinated in a top-down manner by the highest-ranking party leaders. Thus, the party's central leadership controls subordinate party organs and state institutions responsible for policies and processes in all policy spheres in the PRC. The layout of the systems thus conveys the party's cosmogonic vision of how its domain is ideally arranged. While there is disagreement on the number and structure of these systems, ${ }^{3}$ there is consensus that the "propaganda, ideational, and cultural system" (xuanchuan sixiang wenhua xitong 宣传思想文化系统) is of major importance.

In fact, ideology and propaganda have been a quintessential pursuit for the CPC since its first statecraft endeavors in revolutionary enclaves in the 1930s. Ideology, which can be broadly defined as "a symbolic system of meanings and practices to embed the ruling group's beliefs in mass consciousness" (Su 2011: 310), also remains at the heart of the political system of post-Mao China. The PRC as such has been classified as an ideological one-party state, where ideology plays two legitimating roles - the governing role of legitimating the regime's policies and the political role of legitimating the regime itself (Brooker 1995: 15, 91-95). The interrelated ideational and practical aspect of ideology has also been noted by Franz Schurmann in his seminal study of ideology and organization in Maoist China. He treats ideology as a consistent yet changing "systematic set of ideas with action consequences serving the purpose of creating and using organization" through which the CPC "created a web of organization which covers all Chinese society and penetrates deep into its fabric" (Schurmann 1968: 17-8). ${ }^{4}$

In post-Mao China, that is, since 1978, the CPC's guiding thought (zhidao sixiang 指 导思想) encompasses the core ideology of Marxism-Leninism and its derived operational ideologies - Mao Zedong Thought (Mao Zedong sixiang 毛泽东思想), Deng Xiaoping Theory (Deng Xiaoping lilun 邓小平理论), Jiang Zemin's Important Thinking of Three Represents (sange daibiao zhongyao sixiang 三个代表重要思想), and Hu Jintao's Scientific Development Concept (kexue fazhan guan 科学发展观), as well as all the party's other guiding principles (zhidao fangzhen 指导方针), principles (yuanze 原则), and general and specific policies (fangzhen zhengce 方针政策; Heath 2014: 189). Guo Sujian observes that in the contemporary Chinese Leninist party-state, ideology continues to

3 Kenneth Lieberthal distinguishes six systems (listed in Saich 2011: 144), while Zheng Yongnian and Chen Gang identify seven major systems of the CPC's operations: military, political and legal, administrative, propaganda, united front, mass organizations, and organization and personnel (Zheng Yongnian and Chen Gang 2015: 68-9).

4 David Shambaugh's article lists the major works on ideology and propaganda in Maoist China (Shambaugh 2007: 26). 
function as both a means of legitimation and a practical base for the CPC's operation, as it guides the actions of the political elite, justifies the CPC's monopoly on truth, virtues, and power, establishes the party's moral superiority in defining and creating the new socialist moral order, and legitimates its proclaimed historical mission of building socialism (Guo Sujian 2013: 91). Ideology has an interrelated discursive function - besides being "linked to practices, institutions and organization, legitimating and operationalizing their key objectives," ideology also serves the CPC as "a means of control over key vocabularies, linking them with power systems in order to achieve goals" (Brown 2012: 53).

Ideology is no less important for the CPC after 1978 than it was in the Maoist era. Timothy Heath posits that, despite the various transformations in the PRC's politics and the CPC's more pragmatic and rational policy agenda in the post-Mao era, the party reinvigorated its ideology at the beginning of the Hu-Wen era (2002-2012). The CPC's rule is conditioned upon attributing its achievements to its political theory; the party is well aware that "the moment that the citizenry concludes that the government's policy outcomes have little to do with the party's ideology, the argument for the necessity of the CPC's monopoly on power weakens considerably" (Heath 2014: 41). Therefore, the CPC has since 1978 amended Marxist-Leninist and Maoist orthodoxy with an updated theory featuring a more pragmatic and realistic worldview through "a much thinner ideological screen". But in fact, the importance of ideology has grown in comparison to the Maoist era, as today the party-state cannot rely on the Maoist era's egalitarian ideals, mass enthusiasm, coercive violence, and the charismatic power of CPC leadership. The CPC is thus obliged to employ persuasion and manipulation to convince the public of the legitimacy of its rule, and therefore, to articulate "a well-argued and intellectually serious ideology" to support its legitimating arguments (ibid.: 42-43).

The above-described functions of ideology in the post-Mao PRC are effected through propaganda, which can be understood in a party-state context as an "attempt to transmit social and political values in the hope of affecting people's thinking, emotions, and thereby behavior" (Kenez 1985: 4). Anne-Marie Brady argues that the CPC's contemporary thought-work (sixiang gongzuo 思想工作) and thought-management (sixiang guanli 思想管理) have successfully innovated mass communications, media, and the cultural economy to create a "market-friendly, scientific, high tech, and politics-lite" form of propaganda conducive to "stability, harmony, and happiness" (Brady 2012: 1, 201). Kingsley Edney views the CPC's contemporary propaganda as efforts of the party-state to articulate desirable discourses and suppress undesirable ones. Thus, domestic propaganda seeks to reshape politics and society within the PRC, while external propaganda seeks to channel international discourses on China. In other words, domestic ideational and propaganda dynamics greatly determine China's international communication (Edney 2014: 21).

The interrelation of culture, ideology, and propaganda in the contemporary Chinese party-state is not new in Chinese politics. The idea that political power derives from cultural and moral authority has been present in China's diplomacy and governance since its early beginnings. A constructed cultural, political, and historical identity of Chinese civilization (Huaxia 華夏) generated a sense of superiority over surrounding states, which were expected to "come and be transformed" (laihua 來化; Dikötter 1992: 2) by the superior culture of the central polity. Domestically, the emperor was seen as the embod- 
iment of moral and cultural values, while the gentry saw themselves as entitled to rule because of their literacy, education, and morality. Rule by "culture and refinement" (wen 文) was theoretically preferred over rule by “military power" ( $w u$ 武). Late Qing literati inspired by Western models wanted to “awaken the people” (jue min 覺民) to modernity, to transform them, and to instill them with civic values by the means of a new press and education. The CPC was founded in 1921, partly based on the avant-garde ethos of the New Culture Movement of the late 1910s, in which intellectuals called for reevaluating China's traditional sense of itself and for embracing Western cultural, social, and political values. Throughout the 1920s, China's intellectuals increasingly related literature and arts with political ideals. Simultaneously, the Kuomintang claimed to forward both traditional cultural values and modern nationalism during its rule from 1928 to 1949.

The CPC first experimented with embedding culture in its political order in the Jiangxi Soviet of 1931-1934, which introduced cultural organizations and literacy programs as a means of political mobilization. Mao disciplined intellectuals at the Yan'an Forum on Literature and Art in May 1942, when he discussed "revolutionary literature and art" (geming wenyi 革命文艺, which can be alternatively translated as "revolutionary culture"). He specifically called for the subjugation of culture to politics: "The cultural and military fronts are among the fronts where the struggle for people's liberation is fought... The purpose of our meeting today is precisely to ensure that literature and art fit well into the whole revolutionary apparatus as a component part, that they operate as powerful weapons for uniting and educating the people and for attacking and destroying the enemy, and that they help the people fight the enemy with one heart and one mind" (Mao Zedong 1949: 1-2). In the early PRC era (1949-1976), Mao perfected the political employment of culture and education in numerous uncompromising and anti-traditionalist campaigns, such as the Anti-Rightist Movement, the Socialist Education Movement, and the Cultural Revolution, which also carried strong anti-intelligentsia overtones. Zhou Enlai considered cultural and economic diplomacy to be the "two wings" of China's political diplomacy.

After Mao, the CPC continued to pose as a cultural and ideational authority. In the 1980s Deng Xiaoping conceptualized China's future development as encompassing “material civilization” (wuzhi wenming 物质文明) and “spiritual civilization” (jingshen wenming 精神文明). As some Chinese intellectuals were seeking to break away from the political establishment at the time, Deng launched the Campaign against Spiritual Pollution (qingchu jingshen wuran yundong 清除精神污染运动) to fortify the party's ideational domain against liberal ideas. In the 1990s, Jiang Zemin expanded Deng's binary division of China's future development to a tripartite system, adding "political civilization” (zhengzhi wenming 政治文明). As a part of the crackdown on the “superstitious" Falungong in 2000, Jiang also articulated the concept of "scientific civilization" (kexue wenming 科学文明), which contrasted with “superstition and ignorance" (mixin yumei 迷信愚昧; People's Daily 2000). He also included culture in his Important Thinking of the Three Represents, in which he argues that the party "represents the orientation of China's advanced culture". The concept of political civilization and the Three Represents were included in the amendments to the preamble of the PRC's constitution in 2004. In the following decade, $\mathrm{Hu}$ Jintao elaborated on the concept of science and introduced the Scientific Development Concept, which sought to address the income and growth dispar- 
ities spawned by the tumultuous 1990s. Hu's concept also includes an ideational aspect as it seeks to shape and transform a "healthy" worldview and morality. It specifically regards “cultural construction" (wenhua jianshe 文化建设) as on par with the economic, political, and social development of China.

\section{The concept of culture in the Xi era}

The Xi leadership continues to stress the importance of culture in China's overall development. A new formulation was raised in the work report of the Eighteenth Congress of the CPC in 2012, which expands Hu Jintao's previous fourfold development into “five-in-one" (wuwei yiti 五位一体) development by including "building ecological civilization” (shengtai wenming jianshe 生态文明建设). The CPC continues to frame culture within its orthodox worldview as “socialist culture" (shehui zhuyi wenhua 社会主义文 化), or "advanced socialist culture" or "progressive socialist culture" (shehui zhuyi xianjin wenhua 社会主义先进文化). The above-described concept of three civilizations is reflected in the CPC's belief that "the economy is the flesh and blood, politics is the skeleton, and culture is the soul of a society" (zai yige shehuizhong, jingji shi xierou, zhengzhi shi guge, wenhua shi linghun 在一个社会中, 经济是血肉, 政治是骨骼, 文化是灵魂; China Cadre Learning Network 2016). There is also a dialectical relationship between culture and ideology: "culture is the base and carrier of ideology, while ideology is the core and soul of culture" (wenhua shi yishixingtai de jichu he zaiti, yishixingtai shi wenhua de hexin he linghun 文化是意识形态的载体, 意识形态是文化的核心和灵魂; ibid.). Leading propagandist Liu Yunshan 刘云山 argues that “culture is a spiritual banner of a party and of a nation" and that "the building of socialist culture must be guided by Marxism” (Liu Yunshan 2010). Through Shen Haixiong 慎海雄, deputy-director of Xinhua News Agency, the party argues that China's national culture consists of "traditional culture” (chuantong wenhua 传统文化), “ethnic culture” (minzu wenhua 民族文化), “red culture” (hongse wenhua 红色文化), and “contemporary culture” (dangdai wenhua 当代 文化; Shen Haixiong 2014).

Culture is also a means of legitimating the CPC's rule through fostering national sentiment, social cohesion, and loyalty to the party-state. This link is reflected in the concept of "cultural confidence" (wenhua zixin 文化自信). Since its first mention by $\mathrm{Xi}$ Jinping at the thirteenth collective study session of the politburo in February 2014, the notion has been widely debated, lately in relation to the ninety-fifth anniversary of the CPC's founding on 1 July 2016 (SCIO 2016). Cultural confidence complements "confidence in the path, theory, and system of socialism with Chinese characteristics" (Zhongguo tese shehui zhuyi daolu zixin, lilun zixin, zhidu zixin 中国特色社会主义道 路自信, 理论自信, 制度自信). The CPC posits that the “moderately prosperous society” (xiaokang shehui 小康社会) it vows to build by 2021 reflects the immemorial Chinese vision of an ideal society because the concept of “moderate" (xiaokang 小康) prosperity appears first in the Record of Rites 禮記 and the Book of Songs 詩經, where it is translated as "tranquil" or "happy" (e.g., Legge 1876: 317). The excellence of China's culture and national might and the strength of its people justify cultural confidence and pride. In the words of $\mathrm{Xi}$ Jinping: 
Standing on the vastness of 9.6 million square kilometers of land, having absorbed the cultural nutrients accumulated in the long struggles of the Chinese nation, and relying on the majestic strength assembled by the 1.3 billion Chinese people, we are going our own way towards an unprecedentedly large stage with an unprecedentedly strong determination. Chinese people should have this confidence; all Chinese should have this confidence (Zhao Yinping 2016).

As the CPC is increasingly concerned with maintaining power, leadership under Xi views a growing number of domestic issues as a matter of regime security. Domestic cultural security (wenhua anquan 文化安全) is thus an important component of the PRC's national security (guojia anquan 国家安全), which also includes security in politics, social issues, science, information, technology, and all other areas of life in the PRC. An online database search reveals that Chinese scholars started publishing about cultural security in 1999 and the concept received more attention in the 2000s, gaining prominence under Xi's leadership starting in 2012. China's leaders argue that in the contemporary world, influencing people's ideational values is a more effective way of destroying a country than using military or economic power. In other words, culture is a part of the domestic ideational order, whose degradation can lead to the collapse of the regime. Following a statement ascribed to Qing reform-minded scholar Gong Zizhen 竟自珍 (1792-1841) - "in order to annihilate another country, it is necessary to destroy its history; in order to destroy a people, it is necessary to destroy its culture" (yu yao wang qi guo, bi xian mie qi shi; yu yao mie qi zu, bi xian mie qi wenhua 欲要亡其國, 必先滅其史; 欲 要滅其族, 必先滅其文化) - the party sees culture as a potential political threat (China Cadre Learning Network 2016).

The concept of the CPC's domestic cultural security is closely linked to the concept of China's soft power abroad. Joseph Nye's concept of soft power has been widely debated by Chinese academics (Hartig 2016: 64-66), who have developed it into the concept of “cultural soft power" (wenhua ruan shili 文化软实力). It was first voiced in Hu Jintao's report to the Seventeenth Congress of the CPC in 2007, where it was considered one of the major factors determining “comprehensive national power” (zonghe guoli 综合 国力), the sum of a country's political, economic, military, and ideational strength. The CPC's foreign propaganda therefore seeks to construct and project an international image of China as a country with both ancient and modern culture. The CPC wants China to be perceived not only as culturally significant, but also as a stable, responsible, trustworthy, and reliable partner and member of the international community.

The party also hopes to generate acceptance and support of its political system and policies. These efforts are conceived to refute what Chinese policy makers and experts customarily refer to as the "China threat theory" (Zhongguo weixie lun 中国威胁论) and to fight against the Western media's bias against China. Chinese leaders also seek to ameliorate the negative image the regime acquired as a result of the violent suppression of the June 1989 demonstrations, which the CPC has not yet managed to improve. China's public diplomacy therefore seeks to remove this tarnish by presenting a national image of China as a developing country in transition entailing certain difficulties, and/or as a successful model of development based on the so-called Beijing consensus focusing on economic development without necessary political liberalization. In sum, the cultural 
sphere is crucially important in the CPC's domestic ideational order and its international projection. Chinese leaders' statements that "raising China's cultural soft power is a matter of national destiny" (guoyun 国运) are correct in the sense that it conditions the CPC's grip on power.

\section{Raising China's cultural soft power}

The Xi administration's emphasis on cultural work signals its cultural insecurity and awareness of its lack of cultural soft power. These weaknesses are acknowledged in statements claiming that although China has strengthened its cultural work, rather than being a “cultural power" (wenhua qiangguo 文化强国) it is merely a “major cultural country” (wenhua daguo 文化大国) whose cultural soft power does not correspond with its “material hard power" (wuzhi ying shili 物质硬实力) and its economic weight, or in other words, that "the superiority of [China's] cultural resources are not sufficiently well transferred into superiorities in cultural diplomacy" (Zhao Kejin 2014).

Boosting both domestic cultural security and international cultural soft power are part of the CPC's broader long-term objectives for improving domestic governance and raising the PRC's international status. These objectives are entailed for instance in the "Two Centenary struggle objective"5 and the somewhat vaguer Xi Jinping trademark of "realizing the Chinese Dream of the great rejuvenation of the Chinese nation". Improving cultural security and cultural soft power is a part of the CPC's greater emphasis on "propaganda, ideational, and cultural work” (xuanchuan sixiang wenhua gongzuo 宣传思想 文化工作). But while the party does generally distinguish between internal and external propaganda, its approach to domestic cultural security and cultural soft power does not draw the line very clearly and implies a transborder, globalized discursive enterprise targeting both domestic and foreign audiences.

The CPC's concept of cultural work was outlined in Xi Jinping's keynote speech the National Propaganda and Thought-Work Conference on 19 August 2013, which can be taken as the new administration's blueprint for all ideational work. Overall, the party signals that it will intensify and innovate its external and foreign propaganda by "creating and accommodating new concepts, new categories, and new expressions, both domestic and foreign" to create more attractive, appealing, proactive, focused, cutting-edge, and in other ways updated propaganda. It promises to cultivate China's cultural excellence and cultural strength and raise its cultural soft power, with the overall objective of building China into a "socialist cultural power" (shehui zhuyi wenhua qiangguo 社会主义 文化强国). The party also clearly recognizes the importance of China's national image and narrative, both domestically and internationally. One of the major tasks of the party's ideational work is to "grasp the discursive power" (zhangwo huayuquan 掌握话语 权) and to make sure people "comprehensively and objectively understand China and the

5 The “Two Centenary' struggle objective” ('liangge yibai nian' fendou mubiao 两个一百年” 奋斗目标) is a CPC policy goal to double the 2010 GDP and per capita income of urban and rural residents and to finish building a "society of initial prosperity" (xiaokang shehui 小康社会) by the CPC's centenary in 2021, and to make China "a modern socialist country" that is "prosperous and strong, democratic, civilized, harmonious, and beautiful” by the PRC's centenary in 2049 (Baidu Encyclopedia 2017). 
outside world". In this enterprise, the party professes to rely on "explaining China's story" (jianghao Zhongguo gushi 讲好中国故事) and “broadcasting China's voice” (chuanbohao Zhongguo shengyin 传播好中国声音; Xinhua 2013a). The Xi administration has articulated a much more assertive international strategy, which includes exporting, or at least offering, to the world the "China model” (Zhongguo moshi 中国模式) of development, including its values and worldview. In February 2017, Xi remarked that China should "guide" (yindao 引导) the international community in building a new world order and maintaining international security (China Cadre Learning Network 2017). This announcement signals the end of the "hide your capacity and bide your time" (taoguang yanghui 蹈光养晦) low-key approach to international strategy promoted in the 1980s by Deng Xiaoping.

The party declares it will ensure domestic cultural security by maintaining its ideological leadership, cultivating and implementing socialist values, claiming and promoting the exquisite traditional culture of the Chinese nation, preventing and resisting unhealthy cultural influences, and improving overall cultural strength and competitiveness (China Cadre Learning Network 2016). This domestic cultural security strategy extends into the CPC's international cultural power strategy. Echoing central leadership's stance, Zhang Guozuo 张国祚, the head of the National Cultural Soft Power Research, Collaboration, and Innovation Center (Guojia wenhua ruan shili yanjiu xietong chuangxin zhongxin 国 家文化软实力研究协同创新中心), ${ }^{6}$ specifies that strengthening national cultural soft power should entail four major actions: First, the socialist core value system ${ }^{7}$ and the socialist core values outlook ${ }^{8}$ should be cultivated. Second, as the superiority of China's national cultural soft power dwells in its traditional culture, its essence should be promoted and guarded against potential impurities (literally “dross” zaopo 糟粕). Third, cultural industries should be developed. Fourth, ideational and political education in universities should be strengthened. Zhang also argues that culture is at the base of the PRC's international development strategies, such as the One Belt, One Road (OBOR) initiative. According to Zhang, only such cultural framing of the OBOR will forge "a community of common interests, destiny, and responsibility with mutual political trust, economic fusion, and cultural inclusion" (SCIO 2015).

The party has also stated how it will relate China's story, or, in other words, it has outlined its discursive strategy in constructing China's national image. It views culture

6 This consortium of universities, research institutes, and party and state organs was formed in early May 2015, succeeding the Chinese Cultural Soft Power Research Center (Zhongguo wenhua ruan shili yanjiu zhongxin 中国文化软实力研究中心). In the press, it has been lauded as a leading authority on national cultural soft power, yet the institution does not seem to have a publicly known address or website, nor does it publish a publicly available journal.

7 The "socialist core value system" (shehui zhuyi hexin jiazhi tixi 社会主义核心价值体系) was adopted by the Seventeenth Congress of the CPC in 2007 and comprises 1) the guiding thought of Marxism, 2) the common ideal of socialism with Chinese characteristics, 3) national spirit with patriotism at the core, 4) the spirit of the times with reform and innovation at the core, and 5) the socialist concept of honor and disgrace (Baidu Encyclopedia 2017).

8 The “socialist core value outlook" (shehui zhuyi hexin jiazhiguan 社会主义核心价值观) is another component of the socialist core value system. It was adopted by the Eighteenth Congress of the CPC in 2012 and consists of the so-called twenty-four-character definition: 1) value objectives on the national level (wealth, democracy, civilization, harmony); 2) value orientation on the social level (freedom, equality, justice, rule of law); and 3) value criteria on the personal level (patriotism, dedication, honesty, amiability; Baidu Encyclopedia 2017). 
as the most suitable communication channel for "explaining China's story" (or, alternatively, "Chinese stories"). Glorious, ancient Chinese culture should be presented to the world in order to explain China's civilized progress and peaceful development and to elucidate the plentiful meanings of the Chinese Dream. The pivotal notion of the CPC's argument is “uniqueness" or “specificity" ( $t e$ 特), which conceptually links China's “unique" (dute 独特) traditional culture with its “special characteristics” (tese 特色), and thus also with "socialism with Chinese characteristics" (Zhongguo tese shehui zhuyi 中国特色社会主义). The CPC argues along the Marxist line that the country's contemporary situation is preordained by the principles of historical development. Thus, what the party portrays as the continuous and unique five-millennia-long history of Chinese civilization and culture is also what justifies the political order in the PRC. According to $\mathrm{Xi}$ Jinping, in constructing the narrative of China, the party should specifically elucidate the following four points (also known as the "Four Explanations" sige jiang qingchu 四 个讲清楚):

1) The historical traditions, cultural resources, and essential national conditions of every nation are different; therefore the respective national paths to development are also different.

2) Chinese culture accumulates and nourishes the spiritual aspirations of the primordial and advanced Chinese nation.

3) Traditional Chinese culture is the precious asset of the Chinese nation and the source of its cultural soft power.

4) Socialism with Chinese characteristics is rooted in the fertile soil of Chinese culture. It reflects the Chinese people's aspirations, suits the requirements for the development and progress of China, and has ancient historical origins and an extensive practical basis (Xinhua 2013a).

A commentary on Xi's speech published by the People's Daily is more specific about the CPC's argumentation strategy. The "basic logic" (jiben luoji 基本逻辑) behind “China's special characteristics" (Zhongguo tese 中国特色) is that “unique cultural traditions (wenhua chuantong 文化传统), unique historical destiny (lishi mingyun 历史命运), and unique fundamental national conditions (jiben guoqing 基本国情) predetermine the inevitable and suitable path of China's development". This logic should be specifically “analyzed” (jiexi 解析) from the perspective of China's tumultuous history and the Chinese people's perilous ordeal since the beginning of modern history in the mid-nineteenth century. This starting point for argumentation is clearly chosen because, according to the CPC, the 1840s were the beginning of "a century of humiliation" (bainian guochi 百年国耻) inflicted on China by foreign powers. Thus, this decade marks the advent of Chinese people's struggle for modernity, prosperity, freedom, and other values the party claims to perpetrate. The party asserts that if the national strategic narrative follows the historical thread, people will develop "a scientific grasp of contemporary China and of our path, theory, and system" (People's Daily 2013).

At the twelfth collective study session of the CPC politburo in December 2013, Xi Jinping offered further guidance on how to "exhibit the unique charm of Chinese culture in raising national soft power". The party should be modern and innovative, employ vivid imagery to explain China's story, and use plausible and participatory communication to expound the "spirit of Chinese culture" as globally appealing and comprising both time- 
less charm and contemporary values. The party should "speak through history", that is, it should utilize the resources of traditional culture, such as the treasures of the Forbidden City, China's archeological heritage, and ancient writings. It should innovate exchange in the humanities and rely on mass media, social communication, and personal communication. In constructing and transmitting China's “national image" (guojia xingxiang 国家 形象), the CPC should strive to elucidate China as

1) a civilized power possessing a long history, an ethnically diverse yet unified national identity, and a heterogeneous yet harmonious culture;

2) an oriental power boasting clean politics, economic development, splendid culture, a stable society, a united people, and natural beauty;

3) a responsible power that contributes to humankind by effecting peaceful development, promoting common development, and safeguarding international justice;

4) a socialist power that is increasingly open, approachable, optimistic, and energetic.

In boosting cultural soft power, $\mathrm{Xi}$ specifically calls for increasing "international discursive power" (guoji huayuquan 国际话语权) and building an “external discursive system” (duiwai huayu tixi 对外话语体系). China's story, voice, and special characteristics should be explained through new media, and the discourse targeting international audiences should be more creative, appealing, and credible. This foreign discourse is again conceptualized as an extension of domestic ideational work, as Xi calls for stronger positive propaganda focused on China's history and culture via school education, political studies, historical research, film and television productions, literature, and other channels. Patriotic, collectivist, and socialist education should be revised so that people have a correct view of history, nation, state, and culture, and so that they strengthen their confidence in being Chinese. Thus, each out of the 1.3 billion should become a disseminator of Chinese culture, as well as of traditional, Marxist, and socialist values (Xinhua 2013b).

In sum, this survey of the Xi administration's central statements reveals that although the CPC conceptualizes culture in a number of novel ways, it, nevertheless, also continues to grasp culture as a means of fulfilling political objectives in much the same way as it has since at least Mao's consolidation of power in Yan'an in the 1940s. Such use of culture for political ends is not exceptional. The CPC's approach, however, differs from that of democratic states in that it sees legitimation as the most important function of culture, in that this legitimation is used to justify an unattractive non-democratic regime, and in that the party monopolizes domestic visions of national culture and history, while simultaneously suppressing alternative interpretations. Domestic cultural work is a vital part of ideational and propaganda work in instilling internal ideational order and garnering acceptance for the CPC's rule, while cultural diplomacy seeks to establish cultural soft power and win international acknowledgement of the regime. In other words, the CPC uses culture as a means of legitimating its regime both domestically and internationally. The legitimating role of the PRC's cultural diplomacy thus merits expanding one standing definition of China's cultural diplomacy as "foreign communication activity aiming to broadcast China's culture" (Zhao Kejin 2014). The cultural diplomacy of this non-democratic regime can be also defined as the "use of culture in public diplomacy aiming to gain international support and strengthen domestic political order". 


\section{China's public diplomacy apparatus}

The legitimating function of the PRC's cultural diplomacy is revealed also by the structure of what can be called the CPC's ideational apparatus. ${ }^{9}$ As mentioned above, CPC's cultural diplomacy falls within the "propaganda, ideational, and cultural system". Within this and all other systems, work is managed by "central leading small groups" (zhongyang lingdao xiaozu 中央领导小组; CLSG), the highest-ranking party institutions consisting of top leaders who head party and state institutions within the particular system. At the same time, the agendas of some CLSGs cover more than one system and therefore overlap with those of other CLSGs. ${ }^{10}$ In contrast to the top formal organs of the CPC, such as the Politburo Standing Committee and the Secretariat, CLSGs, are informal, evolving task forces operating in non-transparency regarding their membership and operations.

Besides the CLSG for Activities Implementing the Party's Mass Line Education (Zhongyang dangde qunzhong luxian jiaoyu shijian huodong lingdao xiaozu 中央党的群 众路线教育实践活动领导小组), the Party-Building Work CLSG (Zhongyang dangde jianshe gongzuo lingdao xiaozu 中央党的建设工作领导小组), and the Central Guidance Committee on Building Spiritual Civilization (Zhongyang jingshen wenming jianshe zhidao weiyuanhui 中央精神文明建设指导委员会), it is mainly the Propaganda and Ideational Work CLSG (Zhongyang xuanchuan sixiang gongzuo lingdao xiaozu 中央宣 传思想工作领导小组; PIWCLSG) that organizes the party's work within the ideational system. All of the CLSGs concerned with ideational work are headed by Politburo Standing Committee member Liu Yunshan, who is often dubbed by foreign media as China's "propaganda czar". The PIWCLSG also coordinates with other CLSGs or central-level organs involved with ideational operations, for example, with the Cybersecurity and Informatization CLSG (Zhongyang wangluo anquan he xinxihua lingdao xiaozu 中 央网络安全和信息化领导小组) or with the Political Work Department of the Central Military Commission (Zhongyang junshi weiyuanhui zhengzhi gongzuo bu 中央军事委 员会政治工作部).

The PIWCLSG then controls the CPC Central Committee's propaganda department (Xuanchuanbu 宣传部), which in turn "leads" (lingdao 领导) or "guides" (zhidao 指 导 $)^{11}$ all party and state organs of the PRC's ideational apparatus. Through this network, the CPC is able to conduct or control all activities and means involved in communication and the spread of information, such as media, publishing, advertising, information communication technologies, social science research, education, culture, health, sport, and tourism (Shambaugh 2007; Brady 2008: 9-12). Besides domestic/internal propaganda (duinei xuanchuan 对内宣传), the apparatus also covers foreign/external propagan-

9 The term "ideational apparatus" builds on Louis Althusser's concept of ideological state apparatuses (ISAs) that disseminate a particular ruling ideology. Althusser tentatively identifies religious, educational, family, legal, political, communications, and cultural ISAs (Althusser 2014: 243).

10 One source identifies twenty-two central leading and "coordinating small groups" (xietiao xiaozu 协 调小组), some of which were founded alongside the PRC in 1949, whereas others were established only after Xi Jinping assumed power in 2012 (Wang 2015).

11 The term "leadership" (lingdao 领导) means direct tasking and overseeing, whereas "guidance" (zhidao 指导) implies a looser superordinate relationship, often in cooperation with another organ. In practice, the actions of a particular state organ are led and guided by more than one party organ. 
da (duiwai xuanchuan 对外宣传). ${ }^{12}$ The PIWCLSG thus directly controls many of the organs engaged in China's cultural diplomacy, such as the National Internet Information Office, the State Administration of Press, Publication, Radio, Film, and Television, Xinhua News Agency, the National Tourism Administration, and so forth.

The PIWCLSG also articulates the ideational software of China's cultural diplomacy running on the hardware of other systems, mainly the "foreign affairs system" (waijiao xitong 外交系统). This system entails the Foreign Affairs Work CLSG (Zhongyang waishi gongzuo lingdao xiaozu 中央外事工作领导小组) headed by Xi Jinping and coordinates the work of the CPC Central Committee's Propaganda Department and External Liaison Department (Duiwai lianluobu 对外联络部), the State Council, the Ministry of Foreign Affairs, the Ministry of National Defense, the Ministry of Public Security, the Ministry of State Security, the Ministry of Commerce, the Overseas Chinese Affairs Office, and others. The PIWCLSG thus directly formulates or indirectly supervises the ideational message of all of China's cultural diplomacy actors.

Hartig quotes Chinese expert Han Zhaoying (Han 2010: 296) in classifying the central actors of China's public diplomacy into two categories: governmental actors and instruments conducting information programs, and actors conducting educational and exchange programs. Information actors include the State Council Information Office (Guowuyuan xinwen bangongshi 国务院新闻办公室, which is in fact a media outlet of the CPC's Propaganda Department), China's embassies and consulates, the Public Diplomacy Office and the Public Diplomacy Advisory Committee of the Ministry of Foreign Affairs, the Foreign Affairs Committee of the Chinese People's Political Consultative Conference, Xinhua News Agency, China Global Television Network, China Radio International, China Daily, Global Times, and the Beijing Review (Hartig 2016: 84-90).

The Ministry of Education is the primary player in culture and exchange. It is in charge of the State Office of the Leading Small Group for International Promotion of Chinese Language (Guojia Hanyu guoji tuiguang lingdao xiaozu bangongshi 国家汉语国际推广 领导小组办公室; officially translated into English as the Office of Chinese Language Council International), which manages the Confucius Institutes, "the star of China's public diplomacy" (Hartig 2016: 98). These institutes then implement a number of the Ministry of Education's other cultural diplomacy projects, such as the Chinese Bridge (Hanyu qiao 汉语桥) language proficiency competitions.

Another major actor of the cultural and exchange type is the Ministry of Culture, which, often through China Cultural Centers (CCC), organizes Happy Chinese New Year celebrations, China Cultural Years in collaboration with partner countries, art exhibitions, book fairs, movie festivals, and so forth. Other actors include the Chinese People's Institute of Foreign Affairs (CPIFA) and the Chinese People's Association for Friendship with Foreign Countries (CPAFFC), which declare themselves to be NGOs but are closely tied to the Ministry of Foreign Affairs and the People's National Congress. Finally, the Chinese State Forestry Administration and its China Wildlife Conservation Associa-

12 English speakers view the term "propaganda" (xuanchuan 宣传) as having negative connotations, and therefore the CPC tends to use the more palatable term "publicity" in its official English translations, such as in the Publicity Department of the Central Committee of the CPC. 
tion, and the Ministry of Housing and Urban-Rural Development and its Chinese Association of Zoological Gardens engage in China's "panda diplomacy" (Hartig 2016: 90-93).

D'Hooghe lists other central actors involved in the PRC's public diplomacy information program, particularly the People's Liberation Army and the Ministry of National Defense, the Ministry of Commerce, PRC leaders, and the CPC itself. She further considers "sub-state" actors (provincial and municipal governments; here, the term "sub-central" is perhaps more apposite) and "non-state" actors ("civil society" groups, individuals, such as celebrity ambassadors, business companies, "people's" diplomacy associations, intellectual elites, academic institutions, and overseas Chinese) as actors in China's public diplomacy (2015: 132-162). All the actors identified by d'Hooghe and Hartig are ideationally and operationally regulated, supervised, or coopted by party-state mechanisms. One Chinese expert underlines that almost all of the diplomatic activities conducted by so-called non-state and non-governmental organizations should "not be regarded as public diplomacy, but as a special form of traditional government-to-government or semiofficial diplomacy" (Zhao Kejin 2015: 56).

\section{The limitations of China's cultural diplomacy}

There are limitations to and contradictions within the PRC's cultural diplomacy that stem from the nature of the CPC's work. Such issues are widely debated even within China's politically sanitized intellectual establishment beyond the party's central propaganda outlets. For instance, Chinese academic debates at the end of the Hu era as summarized by d'Hooghe pointed out organizational shortcomings, such as the lack of coordination among involved actors, the shortage of public diplomacy professionals, and the absence of an institution exclusively in charge of China's public diplomacy. Some experts criticize the fact that the process is still too top-down, that China's civil society is not mature enough to play a major role, and that the growth of civil public diplomacy organizations should be encouraged by the government. Others argue that China needs to have a better sense of its own identity and needs before it starts building a national image. Others have identified Western hegemony in the global media and discourse or the lack of credibility in China's reporting and the non-appeal of China's values as the principal problems of China's public diplomacy. One academic has specifically commented that China's cultural diplomacy does not address the problem of "liking traditional China but not contemporary China, liking Chinese culture but not Chinese politics, and liking Chinese people but not the Chinese government" (d'Hooghe 2015: 125-128).

In a more recent article written in the Xi era, Zhao Kejin 赵可金, China's leading expert on public diplomacy at the Charhar Institute and the Carnegie-Tsinghua Center for Global Policy, argues along similar lines. He points out that one of the fundamental general traits of culture is its fluidity. Referring to Xi Jinping's statement during a visit to Russia that "cultures, souls, and friendships thrive only if they are exchanged around", Zhao underlines that every country's cultural diplomacy should entail exchange and communication. Without referring specifically to the official cultural security concept, Zhao also posits that cultural soft power is only commanded by strong countries, whereas in weak countries cultural exchange can become a security issue. 
Zhao sees the limitations of China's current public diplomacy as follows:

1) The excessive role of government in drafting and implementing cultural diplomacy objectives and the lack of innovative input from institutions, commercial subjects, and social organizations. The main actor should be society, and government should play only an auxiliary role.

2) Overemphasis on traditional culture and disregard for contemporary popular culture.

3) Confinement of cultural exchange to the elite layers of society and its inaccessibility to people with limited finances or possibilities.

4) Lack of foreign communication methods and perspectives on China. China's cultural diplomacy should respect the values of other cultures and should deemphasize the official institutional perspective and state interests (Zhao Kejin 2014).

Each point in Zhao's critique is directly or indirectly related to the above-illustrated fact that China's leaders conceive cultural work as an act legitimating the power of an authoritarian regime. Zhao first addresses the institutional and processual aspect of China's public diplomacy. The CPC has indeed managed to massively expand China's cultural diplomacy apparatus. A typical self-praising official evaluation of China's rising cultural influence usually lists the expansion of Confucius Institutes, cultural centers, and other state-sponsored outlets of China's soft power, which allegedly produce an avalanche of events that draw in massive audiences. The same push can be seen in the CPC's efforts to acquire tools of international discursive power; the country has raced to establish or purchase media outlets abroad in order to take control of international discourses on China. But it is questionable to what extent the institutional proliferation of cultural diplomacy and media is able to transmit a globally attractive cultural message and transform the audience's perceptions and viewpoints. When the above-quoted Shen Haixiong argues that "we have the ability to create stories of China, and we certainly also have the ability to explain stories of China" (Shen Haixiong 2014), he fails to recognize that not even a massive expansion of and innovation in the ways the CPC tells its tale of China will address the major problem - that the narrator is a dishonest authoritarian government. Stories told by dictators are uninteresting because the general audience is often well familiar with the moral of the tale of the wise and dexterous Party "sacrificing" itself for the good of its inept "subjectizens".

Zhao's plea for more non-Chinese involvement in China's cultural diplomacy bespeaks the conceptual limits of the PRC's ideational order. The dilemma of how to endow the “Chinese essence with Western practicalities” (Zhongti Xiyong 中體西用), which Chinese intellectuals and policy makers faced in the late nineteenth century, has reemerged today in the question of how, and indeed whether, a Leninist ideological party-state can operate in a globalized world of ideas conveyed by a burgeoning free media. On the one hand, Chinese leaders openly seek to emulate the successful cultural diplomacy and soft power of democratic countries. Zhang Guozuo argues that unlike in "Western developed countries", where cultural industries can make up to ten per cent of the GDP (with some twenty-five per cent in the US), in China it is a mere four per cent (Qiushi 2016). Shen quotes Churchill's famous quip that he "would rather lose India than Shakespeare" (Shen Haixiong 2014). Other models of countries with soft power are France, Japan, and South Korea. At the same time, China's leaders seek to bar the corrupting influence of "Western bourgeois and liberal culture", which can not only erode the alleged purity of 
China's culture, but can also topple the entire sociopolitical order of the PRC. Similarly, Chinese political and intellectual circles' indignation at Western hegemony in global discursive space and at the alleged concerted efforts of "anti-China forces" to tarnish China's national image contrasts with the central leadership's desire to catch up with the Western approach to international communication. The CPC's central concept of cultural diplomacy is therefore trapped in the logical pitfall of imitating a phenomenon that it simultaneously views as threatening and unjust.

Another conceptual challenge for the CPC's cultural diplomacy again stems from the domestic political system. Even the CPC's very complex analysis and carefully managed adoption of selected "Western" mores of international communication sooner or later run aground of the CPC's ideological orthodoxy. A good example is the argument of Fan Daqi 范大祺 of the CPC Central Compilation and Translation Bureau (Zhonggong zhongyang bianyiju 中共中央编译局). Fan observes that China is being extruded from global discursive space and her national image is often misunderstood, distorted, or even "demonized". But at the same time, Fan calls for a more elaborate analysis of the response to China's international discourse. Speaking primarily about China's international political communication, he proposes to deemphasize "dull theoretical proselytizing" and instead to imitate Western models by telling stories of China's reform accomplishments or the systemic advantages of the China model. Interestingly, he also believes that "China's international political discourse can to a certain extent improve the projection of China's traditional culture" (Fan 2016). Yet it is precisely the reputation of the PRC's politics that tarnishes the image of China as an appealing cultural power. Similarly, China's ambitious international development initiatives, such as the OBOR, entail a decisively "hard" approach, that is, state-centered, top-down investment, implementation, and labor force transfer, often without regard for local labor and environmental concerns. The soft-power-building enterprise can easily misfire as it is designed to benefit primarily the Chinese side in tandem with local holders of power and capital at the expense of local society.

The CPC's embrace of traditional Chinese culture is also problematic and has been pointed out during previous administrations. Elizabeth Perry describes what she calls a "re-orientation" of propaganda since the 1990s. To reassert its ideational authority and moral credit tarnished by the June 1989 Tiananmen massacre, the party leaned away from ideological orthodoxy and instead started to portray socialism with Chinese characteristics as the successor to traditional Chinese culture and ancient civilization. The rehabilitated traditionalist and culturalist line surprisingly easily mutes the CPC's past anti-traditionalist and internationalist leanings and builds well on the party's patriotic ethos present in its ideational work since its inception in 1921. Both the culturalist and the patriotic argument became the main themes of the Patriotic Education (aiguo zhuyi jiaoyu 爱国主义教育) campaign launched by Jiang Zemin in the 1990s in order for the CPC to resuscitate its ideational hegemony over Chinese society. Perry calls this approach "cultural nationalism" and concludes that the effort "to commingle revolutionary and pre-revolutionary symbolic resources as though there were no inherent contradiction between Confucian 'culturalism' and modern 'nationalism' is but the latest twist in a complicated and circuitous process aimed at justifying the Communist Party's right to rule" (Perry 2013: 25). David Shambaugh moreover notes that by harping on its own uniqueness and specificity, China's national-image-building misses the point of public diplo- 
macy, because the essence of soft power is "to possess national attributes that transcend one's own country and appeal to others. Here, China seems to have few responses other than 'peace and harmony"' (Shambaugh 2013: 169).

The credibility of the party's allusions to cultural history or citations from the Chinese classics is limited. The CPC's mouthpiece's quotation of Lu Xun's famous proclamation that "it is the soul of the people which is precious; only if it thrives can China truly advance" (People's Daily 2013) is an absurdity found customarily in authoritarian speech. Lu was an outspoken critic of Confucianism and traditionalism, but his clash with CPC propagandists in the 1930s suggests that due to his liberal and anti-totalitarian thinking he would have most likely been brutally uprooted as a poisonous weed during the first purge of "counter-revolutionary and reactionary intellectuals" had he lived past the founding of the New China in 1949. Secondly, since Lu Xun called for nourishing the nation's spiritual values, the CPC's policies have inflicted major damage on the souls of Chinese people. The official claims that China has been a pacifist cultural power since time immemorial conflicts with its history of military expansion, attested in the least by the PRC's current borders, which are largely congruous with those secured by Qing empire-building conquest. China's declared resolve to build a harmonious world is refuted by its aggressive demeanor in defending its alleged territorial integrity in border disputes in surrounding seas. The allegedly "biased" Western books on China from a century ago show that China's traditional culture and civilization commanded a much more favorable reputation at the time than does today's PRC, which has been spiritually devastated by thirty years of Maoism and thirty-five years of neo-socialism. Admiration and respect for China's traditional culture is present, for instance, in a book on the country's politics, economics, society, culture, religion, and customs written by Czech sinologist Rudolf Dvoŕák (1900) in reaction to the increased demand for expert information about the country after China's defeat in the Sino-Japanese War (1894-1895).

Shen's quotation of a statement found in the Analects attributed to Confucius - "when distant subjects do not submit, attract them by cultivating refinement and virtue" ( $g u$ yuan ren bu fu, ze xiu wende yi lai zhi 故遠人不服, 則修文德以來之; Shen Haixiong 2014, Yang Bojun 1993: 194) - is a misinterpretation because the passage also extols the equal distribution of wealth ( $g a i$ 蓋), harmony ( $h e$ 和), and security ( $a n$ 安) as necessities of effective governance. But it is precisely these qualities that are missing in today's China riven by a yawning wealth gap and low social mobility, where hundreds of millions of people are concerned more with survival than with culture. It is mainly these immediate concerns that Zhao Kejin's third critical point alludes to. The concept of harmonious society (hexie shehui 和谐社会), which the party claims to draw from the traditional Chinese concept of harmony (he 和), is more a propagandistic image of an ideal world than a serious development plan. The usage of the ancient term by CPC propagandists thus articulates the lack of harmony in today's China. There is also no basis to conclude that contemporary China has preserved its traditional culture more than other countries, and Zhao's criticism of the excessive focus on tradition in China's cultural diplomacy therefore seems valid also for the domestic debate on China's cultural identity. One attentive observer of contemporary China quotes Han Han 韩寒, a blogger once critical of the government, on the future of Chinese culture: "We can't always use pandas and tea... What else do we have? Silk? The Great Wall? That isn't China” (Osnos 2015: 176). 
The credibility of the CPC's argument of China boasting a lasting and refined cultural tradition is also refuted by “seeking truth from facts" (shi shi qiu shi 实事求是). As elsewhere today, in China there is a correlation between cultural creativity and commercial dynamics, which is particularly evident in the party's technocratic resolve to reform the "cultural system" to profitably discharge "cultural products" (wenhua chanpin 文化 产品) made by “cultural industries" (wenhua chanye 文化产业) and "cultural institutions" (wenhua shiye 文化事业). But in the PRC, state-supported mercantilist pressure coalesces with coercion, which seeks to purge culture of all politically subversive potential. In the Maoist era, the party's radical sociopolitical projects and anti-traditionalist campaigns wreaked immense havoc on Chinese culture. The most notorious is perhaps the "Destroy the Four Olds" campaign unleashed during the Cultural Revolution in 1966, which brought about the barbaric destruction of oceans of cultural relics, including the family mansion and cemetery of Confucius, the trademark of today's PRC's rehabilitation of traditional Chinese culture.

In the post-Mao era, the CPC's shelving of abstract communist tenets and their replacement with the dictum of development and wealth as pillars of its ideational order has led to irreversible losses in material and intangible culture. Myriad centuries-old towns and villages with traditional cultural practices surviving "construction" and "modernization" since 1949 have been razed in the reform era since 1978. The destruction of old Beijing accelerated by official efforts to portray the capital as a thriving modern metropolis during the 2008 Olympics is a case in point (Yardley 2006). Another tragic example is the razing of old Kashgar, Yarkend, and other ancient Silk Road oases, where the cultural barbarity of the communist party-state bonded with the majority nationality's repression of a dissenting ethnic minority (Levin 2014). Altogether, the post-Mao construction boom wiped out tens of thousands of historical sites, possibly more than the infamous Cultural Revolution (Branigan 2009). The propagandistic mantra that China is a large and populous country boasting a rich, ancient, and exceptional culture therefore proves self-defeating because it implies that the party's governance inflicted unparalleled damage on Chinese culture. It is precisely the cultural governance of the CPC that destroyed China's image as a cultural power.

The credibility of the CPC's cultural rhetoric is also compromised by the fact that the party keeps exerting concerted efforts at curtailing cultural expression that conflicts with its political interests. Zhao Kejin points out that culture resembles floating water in that it only releases its drive when it circulates freely in a society (2014). Being an intangible expression of free will, culture is not likely to thrive in an unfree polity where ideas are often censored and criminalized. The CPC states that "cultural exchange is just like a classical principle of modern management: if two people each have an apple and exchange it, they both end up having one apple. Whereas if they each have an idea and exchange it, they both end up having two ideas" (Shen Haixiong 2014). But the CPC strictly polices the free flow of ideas; indeed, many people are in prison in the PRC at this moment for trying to "exchange apples".

Despite all its assertions of innovation and reform in the cultural sphere, the reality is that in the twenty-first century the Chinese party-state continues to ban inconvenient artistic works and persecute critical artists in much the same way it has done since the beginnings of its cultural governance. Under Xi Jinping, the troubled relations between 
the CPC and artists and intellectuals have culminated in a massive crackdown on civil society, lawyers, NGOs, ethnic minorities, religious communities, non-political education, and other discontents of the ideational order engineered by the CPC. Ironically, it is often these artists and liberal personages who become globally respected icons and therewith enhance China's cultural soft power. Indeed, the fame of artists like Gao Xingjian, Ai Weiwei, Yan Lianke, and others implies that China's culture can do very well when it is not used as the political instrument of a draconic regime.

In order to deliver on its promise to build a modern state and society, the party must allow for the free flow of ideas but has not done so yet. The use of culture in communication with foreign publics can be hardly effective when it advocates authoritarian ideology and practices. The overall lack of truthfulness in the CPC's statements is perhaps the gravest obstacle to telling China's story in a way that the international audience might find plausible and attractive. This shortcoming, moreover, violates a classical Chinese rule of discourse attributed to Confucius: "if names are incorrect, then what is said cannot be followed; if what is said cannot be followed, then tasks cannot be accomplished" (ming bu zheng, ze yan bu shun; yan bu shun, ze shi bu cheng 名不正, 則言不訓; 言不訓, 則事 不成; Yang Bojun 1993: 144). In other words, if the CPC's international communications are not truthfull, China's unfavorable national image in democratic countries is unlikely to change.

\section{Conclusion}

This survey of the ideational and institutional framework of China's cultural diplomacy under Xi Jinping's administration since 2012 shows that central leadership understands cultural governance primarily as a political act of creating an authoritarian ideational order. By extension, it envisions China's cultural diplomacy as a process of external propaganda, which seeks to generate favorable international perceptions and to strengthen the domestic political regime. To achieve domestic and international acceptance, the CPC uses the argument of "specificity" to link the purpoted uniqueness of China's culture and the specificity of China's model of development. The allegedly singular "China's story" told by the CPC has several interrelated narrative lines - Marxism-Leninism, Maoism, authoritarianism, and cultural nationalism.

Geremie Barmé writes that attempts by governments or cultural “... authorities, regardless of whether elected or self-appointed to define or articulate cultural nationhood and boundaries can be deadening" (Barmé 2012). But when culture is coopted by an authoritarian government it can be even more deadening. The credibility of the PRC's cultural diplomacy remains compromised by the authoritarian dimension of the CPC's approach to culture and cultural governance. Regardless of how many resources the CPC invests in its propaganda, the truth remains that contemporary China is not a country where the party-state makes culture thrive. It remains to be seen whether and how the Xi administration's cultural diplomacy will resolve the "contradictions in ambition, rhetoric, and reality" of the PRC's soft power strategy (Rawnsley 2015: 468). As the success of communication depends to a large extent on whether and how the target audience receives the message of communication, foreign publics are unlikely to empa- 
thize and accept China's leaders' advocacy of authoritarianism in the way described by Czesław Miłosz. Even a superb marketing campaign is unlikely to help a disreputable peddler sell unattractive goods to well-informed buyers on the global market of ideas in the twenty-first century.

The above survey of the central concept of China's cultural diplomacy also generates follow-up questions for further research. Jian Wang calls for employing Frank Pieke's perspective of party-state as society in looking at China's public diplomacy and contemporary China in general (Wang, ed. 2011: 17; Pieke 2009: 12-15). When it is applied to the above findings, China's cultural diplomacy should not be examined solely as a set of ideational principles enforced in a top-down manner by institutional networks and mechanisms, but also as the actions of individual actors who do not necessarily communicate and project China's culture in accordance with the central vision. The CPC is not a monolithic entity, and therefore observing whether and how particular party groupings, constituencies, and networks envision culture and cultural work, and whether and how these differences resonate in China's outlook on cultural diplomacy, could be interesting. Another question is how the cultural agenda of the ideational system relates to China's commercial, political, and military interests, and whether and how these concerns are taken into consideration by the country's cultural diplomacy actors.

Neither the outline above nor the existing literature on the institutional network of China's cultural diplomacy provide much detail on how the above-described central vision is implemented by particular central actors, for instance, China's diplomatic missions, Confucius Institutes, China Cultural Centers, and other institutions, or on how their printed materials, websites, and other media related to cultural diplomacy are designed. It is also important to observe how China's cultural diplomatic practice varies in a particular regional context, and to what extent this regional variation is reflected on or initiated by central leadership. The role of central authorities is an interesting issue also in looking at cultural diplomacy conducted by China's sub-central and "non-state" actors. An issue with significant overlap is to what extent, based on a particular message and way of conducting cultural diplomacy, sub-central actors can be considered non-state actors. The same probe should apply to individual actors, where the interesting question is to what extent and why are the messages broadcast by individual actors in China's cultural diplomacy different from or the same as those described above in this article.

These issues reflect the fact that the central vision of cultural work is necessarily adapted, shifted, ignored, or even contested in a variety of ways by all actors who conduct China's cultural diplomacy. Fortunately, China's story is told to the world by many narrators besides the primarily politically motivated central leadership of the CPC. Such diversity will likely increase and more contesting narratives of China will emerge. These probable developments will be beneficial to China's cultural life. At the same time, recent developments show that diversification in politics often makes the CPC feel cornered, forcing the party to defend its position by strengthening its hold on a particular issue, as can be seen above in the party tightening its grip on sensitive ideational matters and politically subversive constituencies. Therefore, in the future it will remain important to keep observing central versus non-central dynamics in Chinese culture and cultural diplomacy, as the interplay between contesting visions and actors is likely to continue and become more sophisticated. 


\section{REFERENCES}

Baidu Encyclopedia (Baidu baike) 2017. Accessible at https://baike.baidu.com/ (accessed 02-08-2017). Barmé, Geremie (2012). "Telling Chinese Stories." Talk at the University of Sydney on 1 May, 2012. The China Story, undated. Accessible at https://www.thechinastory.org/telling-chinese-stories/ (accessed 06-01-2017).

Brady, Anne-Marie (2008). Marketing Dictatorship: Propaganda and Thought Work in Contemporary China. Lanham: Rowman and Littlefield.

Brady, Anne-Marie (2012). "Introduction." In: A. Brady (ed.), China's Thought Management. Abingdon: Routledge, 1-8.

Branigan, Tania (2009). "China Loses Thousands of Historic Sites." The Guardian, 14 December, 2009. Accessible at https://www.theguardian.com/world/2009/dec/14/china-historic-sites-survey (accessed 10-08-2017).

Brooker, Paul (1995). Twentieth-Century Dictatorships: The Ideological One-Party States. Basingstoke: Macmillan.

Brown, Kerry (2012). "The Communist Party of China and Ideology." China: An International Journal 10.2: 52-68.

China Cadre Learning Network (2016). “Xi Jinping de wenhua anquanguan 习近平的文化安全观” [Xi Jinping's Cultural Security Concept]. China Cadre Learning Network [online], 15 April, 2016. Accessible at http://www.ccln.gov.cn/hotnews/182276.shtml (accessed 06-01-2017).

China Cadre Learning Network (2017). “Xi Jinping shouti ‘liangge yindao’ you shenyi” 习近平首提“两 个引导”有深意” [The ‘Two Guidances' Concept Raised for the First Time by Xi Jinping Deeply Meaningful]. Accessible at http://www.ccln.gov.cn/hotnews/230779.shtml (accessed 15-08-2017).

CSIS [Center for Strategic and International Studies] (2016). "How are Global Views on China Trending?" Accessible at http://chinapower.csis.org/global-views/ (accessed 06-01-2017).

d'Hooghe, Ingrid (2015). China's Public Diplomacy. Leiden: Brill.

Dikötter, Frank (1992). The Discourse of Race in Modern China. Stanford: Stanford University Press.

Dvořák, Rudolf (1900). Č́na: popis ř́se, národa, jeho mravů a obyčejů [China: a Description of the Empire, the People, Their Mores, and Customs]. Prague: Josef Springer.

Edney, Kingsley (2014). The Globalization of Chinese Propaganda: International Power and Domestic Political Cohesion. New York: Palgrave Macmillan.

Fan Daqi 范大祺 (2016). “Qianyi woguo duiwai zhengzhi huayu tixi jianshe wenti 浅议我国对外政治 话语体系建设问题” [Brief Discussion of Problems in Building China's External Political Discourse System]. Chinese Academy of Social Sciences Online, 11 October, 2016. Accessible at http://www.cssn .cn/zzx/yc_zzx/201610/t20161011_3229966.shtml (accessed 06-01-2017).

Guo, Sujian (2013). Chinese Politics and Government: Power, Ideology and Organization. London: Routledge.

Han, Zhaoying (2010). "China’s Public Diplomacy in a New Era." In: Z. Zhu (ed.), The People's Republic of China Today: Internal and External Challenges, Singapore: World Scientific, 291-310.

Hartig, Falk (2016). Chinese Public Diplomacy: The Rise of the Confucius Institute. Abingdon: Routledge.

Heath, Timothy (2014). China's New Governing Party Paradigm: political Renewal and the Pursuit of National Rejuvenation. Farnham: Ashgate.

Kenez, Peter (1985). The Birth of the Propaganda State: Soviet Methods of Mass Mobilization, 1919-1929. Cambridge, Cambridge University Press.

Legge, James (1876). The Chinese Classics: Volume III. - The She King; or, The Book of Poetry. London: Trübner and Co.

Levin, Dan (2014). “China Remodels an Ancient Silk Road City, and an Ethnic Rift Widens.” New York Times, 5 March, 2014. Accessible at https://www.nytimes.com/2014/03/06/world/asia/china-remodels -an-ancient-silk-road-city-and-an-ethnic-rift-widens.html (accessed 10-08-2017).

Liu Yunshan 刘云山. 2010. “Zhongguo tese shehui zhuyi wenhua jianshe de shijian tansuo he lilun sikao 中国特色社会主义文化建设的实践探索和理论思考” [Practical Exploration and Theoretical Deliberations on Building of Socialist Culture with Chinese Characteristics]. Qiushi [online], 8 September, 2010. Accessible at http://www.qstheory.cn/zxdk/2010/201020/201010/t20101012_52121 .htm (accessed 06-01-2017). 
Mao Zedong 毛泽东 (1949). Zai Yan'an wenyi zuotanhuishang de jianghua 在延安文艺座谈会上的讲 话 [Talks at the Yan'an Forum on Literature and Art]. Beijing: Jiefang.

Miłosz, Czesław (1992). Zotročený duch [The Captive Mind]. Prague: Torst. [Czech edition.]

Osnos, Evan (2015). Age of Ambition: Chasing Fortune, Truth, and Faith in the New China. New York: Farrar, Straus, and Giroux.

People's Daily (2000). "Jiang Zemin canguan 'chongshang kexue wenming, fandui mixin yumei' daxing tupianzhan he Zhongguo zhuanli shiwu nian chengjiuzhan 江泽民参观崇尚科学文明, 反对迷信愚 昧'大型图片展和中国专利十五年成就展” [Jiang Zemin Visits the Exhibition of Posters on “Uphold Scientific Civilization, Oppose Superstition and Ignorance' and of Fifteen Years' Patent Accomplishments], 3 April 2000, 1. Accessible at http://people.com.cn/GB/channel1/10/20000629/122833.html (accessed 15-08-2017).

People’s Daily (2013). “Keguan renshi dangdai zhongguo yu waibu shijie 客观认识当代中国与外部 世界” [Objective Knowledge of Contemporary China and Outside World]. People's Daily [online], 30 August 2013, 1. Accessible at http://opinion.people.com.cn/n/2013/0830/c1003-22743925.html (accessed 10-08-2017). Also in: People’s Publishing (ed.), Xuexi Xi Jinping zongshuji de 8.19 zhongyao jianghua 学习习近平总书记 8.19 重要讲话 [Studying General Secretary Xi Jinping's Important Speech of August 19], Beijing: People's Publishing, 29-31.

Perry, Elizabeth J. (2013). Cultural Governance in Contemporary China: "Re-Orienting" Party Propaganda. Harvard-Yenching Institute Working Paper Series. Harvard University, 17 May 2013. Accessible at http://www.harvard-yenching.org/features/hyi-working-paper-series-elizabeth-perry (accessed 06-01-2017).

Pew Research Center (2016). “Opinion of China." Accessible at http://www.pewglobal.org/database/indicator /24/survey/18/ (accessed 06-01-2017).

Pieke, Frank N. (2009). The Good Communist: Elite Training and State Building in Today's China. Cambridge: Cambridge University Press.

Qiushi (2016). “Ruhe tigao woguo de wenhua ruan shili 如何提高我国的文化软实力” [How to Raise Our Country's Cultural Soft Power]. Qiushi [online], 23 May 2016. Accessible at http://www.qstheory .cn/zhuanqu/qsft/2016-05/23/c_1118913628.htm (accessed 06-01-2017).

Rawnsley, G. D. (2015) "Chinese International Broadcasting, Public Diplomacy and Soft Power." In: G. D. Rawnsley and M. T. Rawnsley (eds.), Routledge Handbook of Chinese Media. New York and London: Routledge, 460-475.

Saich, Tony (2011). Governance and Politics of China. Basingstoke: Palgrave.

SCIO [State Council Information Office] (2015). “Zhang Guozuo: gongjian 'yidai yilu' libukai wenhua ruan shili 张国祚: 共建“一带一路”离不开文化软实力” [Zhang Guozuo: Cultural Soft Power Indispensable in Joint Building of the One Belt One Road]. SCIO [online], 24 June 2015. Accessible at http://www.scio.gov.cn/ztk/wh/slxy/slzf/Document/1438457/1438457.htm (accessed 06-01-2017).

SCIO [State Council Information Office] (2016). "Xi Jinping zongshuji guanyu 'wenhua zixin' de zhongyao lunshu 习近平总书记关于 ‘文化自信” 的重要论述” [Important Statements of General Secretary Xi Jinping on 'Cultural Confidence']. SCIO [online], 30 August 2016. Accessible at http://www.scio .gov.cn/zxbd/tt/Document/1489005/1489005.htm (accessed 06-01-2017).

Shambaugh, David (2007). "China's Propaganda System: Institutions, Processes, and Efficacy." The China Journal 57, 25-58.

Shambaugh, David (2013). China Goes Global: The Partial Power. Oxford and New York: Oxford University Press.

Shen Haixiong 慎海雄 (2014). “Shuli gaodu de wenhua zixin, jianghao Zhongguo gushi 树立高度的文 化自信, 讲好中国故事” [Establishing a High-degree Cultural Confidence, Explaining China’s Story]. CPC News Online, 4 November 2014. Accessible at http://theory.people.com.cn/n/2014/1104/c40531 -25972996.html (accessed 10-08-2017).

Schurmann, Franz (1968). Ideology and Organization in Communist China. Berkeley and London: University of California Press and Cambridge University Press.

Su, Xiaobo (2011). "Revolution and Reform: the Role of Ideology and Hegemony in Chinese Politics." Journal of Contemporary China 20.69, 307-326.

Wang, Jian (ed.) (2011). Soft Power in China: Public Diplomacy through Communication. New York: Palgrave Macmillan. 
Wang Shu 王姝 (2015). “Zhongyang lingdao xiaozu yu 22 ge, Xi Jinping ren 4 xiaozu zuzhang 中央领导 小组逾22个, 习近平任 4 小组组长” [Central Leading Small Groups Exceed Twenty-Two, Xi Jinping Heads Four]. The Beijing News, 31 July 2015. Accessible at http://news.china.com.cn/2015-07/31/content 36190622.htm (accessed 06-01-2017).

Xinhua (2013a). "Xi Jinping: yishi xingtai gongzuo shi dangde yixiang jiduan zhongyao de gongzuo 习近平: 意识形态工作是党的一项极端重要的工作” [Xi Jinping: Ideological Work Extremely Important for the Party]. Xinhua Online, August 2, 2013. Accessible at http://news.xinhuanet.com /politics/2013-08/20/c_117021464.htm (accessed 15-08-2017).

Xinhua (2013b). "Xi Jinping: jianshe shehui zhuyi wenhua qiangguo, zhuoli tigao guojia wenhua ruan shili 习近平: 建设社会主义文化强国, 着力提高国家文化软实力” [Xi Jinping: Building Socialist Cultural Power, Raising National Cultural Soft Power]. Xinhua Online, 31 December 2013. Accessible at http://news.xinhuanet.com/politics/2013-12/31/c_118788013.htm (accessed 06-01-2017).

Yang Bojun 楊伯峻 (ed.) (1993) Lunyu jinyi 論語今譯 [Analects with Modern Translation]. Jinan: Qilu shushe.

Yardley, Jim (2006). “Olympics Imperil Historic Beijing Neighborhood." New York Times, 12 July 2006. Accessible at http://www.nytimes.com/2006/07/12/world/asia/12beijing.html (accessed 10-08-2017).

Zhao Kejin 赵可金 (2014). “Zhongguo wenhua waijiao de wenti yu silu 中国文化外交的问题与思路” [Questions and Reflections on China's Cultural Diplomacy]. Gonggong waijiao jikan 2014.2: 19-25. Accessible at http://www.pdcec.com/bencandy.php?fid=176\&id=17611 (accessed 06-01-2017).

Zhao Kejin 赵可金 (2015). "Public Diplomacy, Rising Power, and China's Strategy in East Asia." In: J. Melissen and Y. Sohn (edd.), Understanding Public Diplomacy in East Asia: Middle Powers in a Troubled Region. New York: Palgrave Macmillan, 51-78.

Zhao Yinping 赵银平 (2016). “Wenhua zixin - Xi Jinping tichu de shidai keti 文化自信 - 习近平提出 的时代课题” [Cultural Confidence - Xi Jinping Raises a Hot Issue]. Xinhua Online, 5 August 2016. Accessible at http://news.xinhuanet.com/politics/2016-08/05/c_1119330939.htm (accessed 06-012017).

Zheng Yongnian, and Chen Gang (2015). “The Chinese Communist Party: An Institutional Perspective.” In: David S. G. Goodman (ed.), Handbook of the Politics of China. Cheltenham: Edward Elgar, 57-75. 